\title{
Are Entrepreneurship, Communities and Social Transformation Related?
}

\author{
Maria Daskalaki (Kingston University, School of Management) \\ Daniel Hjorth (Copenhagen Business School) \\ Johanna Mair (Hertie School of Governance/Stanford University)
}

\begin{abstract}
This paper explores new forms of organising (and organisation-creation) in relation to entrepreneurship and social transformation. In particular, in the dialogue that follows in this issue, we initiate a discussion regarding the ways through which social transformation is or can be related to community action and public and/or social entrepreneurship. By focusing on socio-economic environments in flux, we suggest that emerging alternative initiatives are not simply oppositional, resistance forces, but new organizing assemblages that co-constitute new social realities that urgently need to be actualized. We conclude the paper with a number of theoretical propositions, which as we suggest, instigate the study of embedded and socially transformative organizing.
\end{abstract}

Keywords: Communities, Entrepreneurship, Organizing, Transformation. 


\section{Entrepreneurship studies: Moving on}

The 1980s and 1990s can be considered as 'growth decades' for entrepreneurship research (Katz, 2003; Hjorth, 2003) with 'renewal' thinkers like Kirzner, Hayek and Schumpeter (see Landström \& Lohrke, 2012) dominating the discipline-forming discourse. Admittedly, sociological, anthropological, and political science have had much less impact on entrepreneurship studies, which got 'established' primarily as a management school discipline with its usual mix of economics and psychology (see also Stewart, 1989; Reynolds, 1991). Of immediate importance to expanding our studies of entrepreneurship was then to include a wider academic discourse outside these disciplines.

Researchers urged that entrepreneurship studies should remain on the move (Steyaert \& Hjorth, 2003; 2006; Hjorth \& Steyaert, 2004; 2009). As a result, during the last decade, there was an attempt to include other academic communities, incorporating broader discussions on paradigms, theories, methodological developments, level and objects of analysis and the like. Accordingly, social entrepreneurship studies as a distinctive domain emerged as a means to address old and new social problems (Mair and Marti, 2006) and gained momentum across geographies (Steyaert \& Katz, 2004; Kerlin, 2010; Peredo \& Chrisman, 2006; Mair, Robinson \& Hockerts, 2006; Steyaert and Hjorth, 2006; Ziegler, 2009; Fayol \& Matlay, 2010; Kickul and Bacq, 2012; Bjerke \& Karlsson, 2013; Tedmanson et al., 2012). These approaches were distinguished by drawing upon genuinely multidisciplinary and multilevel frameworks in creation of knowledge. 
Recently, the financial crisis with its severe social implications, has nurtured an increased interest in public entrepreneurship, civic organisation, translocal, democratic movements and self-organising local economies (Hjorth, 2013; Daskalaki, 2014). South Europe is struggling to find routes out of the recession and communities are forming new solidarity-based organisations, which seek to generate sustainable economies with greater social capacities. Likewise, the US shows signs of increasing fragmentation and social tension, as well as civic mobilisation and community-led initiatives. In this socio-economic context, how are entrepreneurship, communities and social transformation related? This Dialogue Issue is our attempt to address this question.

\section{Entrepreneurship and social transformation}

In contrast to commercial entrepreneurship where value is conceptualized as defined by consumers and measured in monetary terms (Steyaert \& Katz, 2004; Mair \& Marti, 2006; Hjorth \& Bjerke, 2006), entrepreneurship geared towards social change relies on a collective capacity to create organization that generates value for citizens, measured in greater possibilities for living. In this perspective, entrepreneurship is understood as conceptually distinct from society but can constitute a social force and not simply an economic instrument (Steyaert \& Hjorth, 2003; Mair, Battilana and Cardenas, 2012).

Actually, understanding entrepreneurship as part of society (and not simply the economy) was already exemplified in the social anthropologist Fredrik Barth's (1963) study of entrepreneurs' role in social change. Accordingly, entrepreneurship triggers and is triggered by social dynamics. In such dynamics what is lacking is organization 
of resources, people, and information; thus the creation of organization is one way through which the social force of entrepreneurship is constituted (Katz \& Gartner, 1988; Gartner, Starr \& Bird, 1992; Gartner, 2012; Hjorth, 2012). Empirically, this is the social context in which creative assemblages, that have the capacity for intended and unintended socially transformative events, emerge (Daskalaki, 2014).

The 2008 global financial and social crisis shows that the collective capacity for creating and organizing alternative assemblages is key to achieving social transformation. Social and public entrepreneurship research already started unpacking the potential of entrepreneurship to make the world become differently, or at least make local social realities achieve being in new and surprising ways. Social transformation, in this context, relates to the co-production, re-assembling the social into alternative forms to make it innovative. This is not the public entrepreneurship that tactically makes use of worn out dominant strategies. It is not only about protesting and organizing in the 'square', but also co-constituting other organisational forms that embed local, situated victories into new, more democratic institutions and/or institutional models.

New socio-ecological, cultural and financial landscapes might presently call for a multiplicity of models rather than the continuation of a predominantly northern model. Can contextually specific knowledge be used in new localities? Is there such cross-appropriation (Spinosa, Flores \& Dreufys, 1997) in the 'spread' of resistancemovements? Are we seeing a comeback of the public sphere and a differently organized community that morphs and swarms according to where and when the event of entrepreneurial action is most needed? The public, characterized by 
transparency and openness, anchored in the political sovereignty and dignity of the citizens, belongs to no one in particular and can therefore be the place from which new forms of sociality, a collective investments in a desired image, which produce an assemblage, a heterogeneous multiplicity united by co-functioning and sympathy, can emerge.

The communities that we refer to, as a response to social and financial challenges, increasingly engage with 'public entrepreneurial' practices (Hjorth, 2013), reorganizing, building new networks of care and inhabiting emerging urban activist/creative spaces. This shows a change in the social capacity of society, a change that gives rise to several local and trans-local initiatives and new organizational forms that strive to alter the social landscape. In this Dialogue Issue, we foreground the collective dimensions of entrepreneurship and go one step further to suggest that entrepreneurship is also inherently political. Through that, we turn the focus on how to create new resources or new combination of existing ones, how to use them and distribute them, and how to distribute access to what comes out of opening new possibilities. Contributions to this Issue explore this political aspect as related to the collective capacity of entrepreneurial communities to transform and, through that, create value for society.

We see everything from the creation of new resources - like social media tools - to the more or less radical tactical re-organisation of existing ones so as to make the productive in surprising ways (de Certeau, 1984). Via these new organisational forms and spaces, individuals and networks enhance their collective capacity by assembling active forces and directing them via new organisation. Creative activities assemble 
local skills, capabilities and networked/digital relationships to build cultural-social values that are necessary for nurturing and maintaining community life. Can these collective assembling processes really constitute new domains in public life?

Embracing therefore transformative insinuations (de Certeau, 1984; Mair, Marti \& Ganly, 2007), we want to explore whether entrepreneurial initiatives nurture the emergence of bottom-up social transformations that are neither rigid nor bureaucratic; that are neither formal nor fixed (Hardt \& Negri, 2012). In particular, can social or public entrepreneurship create new institutional orders and ultimately, new models of citizenship? Can the local self-organization initiatives be transformed into a space where new social movements are born and fuelled? And if yes, what are the barriers, contested practices as well as supporting processes involved in embedding subversive initiatives, disrupting established processes and achieving new organizational arrangements?

\section{The starting point}

We encourage studies, which will provide empirical evidence on how recently empowered productive forces of societies can be translated into organisation arrangements of lasting local community support (Mair et al., 2012) and new forms of civic life. We propose the study of the triptych entrepreneurship-communitiestransformation through a number of distinctive yet interrelated (and sometimes contested) research agendas. Accounting for a variety of cultural/national, institutional and socio-economic contexts, we view social transformation as an embedded and multi-faceted phenomenon and focus on how 'organization', 'management', and 'entrepreneurship' are now being re-shaped by the dynamics that 
are transforming work, employment and societal and institutional relations. The following areas of research - addressed by the contributors to this Dialogue Issue, have already begun drafting a preliminary propositional framework through which we can initiate our studies of embedded transformative entrepreneuring.

To begin with, Martí and Fernández study citizen mobilization in the case of Mortgage Victim Platform in Spain, and show how emotions and relationality play a role in forming entrepreneurial agency. Fotaki asks whether coproduction/design/management of public services, the involvement of users/citizens is indeed a way to new public values (in the broad sense) being restored, or whether this is a beginning of the end. She points out that this represents a new area for organisation- (and entrepreneurship) studies, with several challenges on the route to a more thorough understanding of whether democratization is part of this form of public entrepreneurship. Tedmanson, Essers, Day and Verduyn seek to move away from the individualistic and normative yoke the study of entrepreneurship has come under. They urge us not to romanticize collective entrepreneurship and an idealized commons. Instead, they stress the simultaneously transformative and exploitative elements of communal entrepreneurship. Kokkinidis relates not the least to Martí and Fernández' and Fotaki's discussions in his study of two workers' collectives in Athens. However, in moving away from an individualistic understanding of entrepreneurship, it is resonant with Tedmanson et al's and Beyes' studies too. Kokkinidis highlights the political dimension of collective entrepreneurship and shows how such collective and affective relationships bring about new drivers of social change and new ways of living together. Finally, in his provocatively entitled essay 'Fictions of the possible,' Beyes explores the relationship between art, the city 
and public entrepreneurship. He relates this to sociological studies showing how a more general aestheticization of the social (the creative self, public space, social media expression) has led to a greater appreciation of the role of art in the creation of social value. With reference to a recent 'art intervention', Beyes brings us to a renewed understanding of the role of urban art in the study of public entrepreneurship.

\section{Future directions}

Introducing the above contributions, we re-introduce the study and understanding of social and/or public entrepreneurship in several respects. First, we highlight the transformational capacity of entrepreneurial collaborative practices in contexts of instability and flux to create new forms of sociality and interventionary citizenship. Breaking from the individualist approaches of entrepreneurial discourse, we foreground a collective dimension of entrepreneurial activity and reflect upon the collective, self-organizing capacity of social initiatives. We point to the need to study the alternative organizing processes through which these social initiatives create shared forms of sociality and bring about new forms of collective co-existence. Highlighting the inherently political character of entrepreneurship, we also propose that the transformational potential for self-organized initiatives means that their social struggles and social embeddedness should not be confined to the local. Instead, transformational self-organized activities have to gradually become embedded, part of the commons that is, multitudes of an active project of re-assembling new social, cultural and economic realities.

Second, we highlight the importance of studying the processes of emergence, evolution and learning that take place in social/activist movements and community- 
based social initiatives; this requires in-depth, bottom-up approaches that focus on people - communities in action - directly affected by austerity policies and not just activists' groups. Affect, for example, plays a big role in mobilizing seemingly heterogeneous communities and creating heterotopic spaces in which lived togetherness is maintained and strengthened. Indeed, appropriation, subversion and inhabitation of these spaces could constitute creative collaborations, which result in new constellations, which constantly expand to include the invisible and the marginalized.

Third, we study how creative-tactical re-arrangements by im/material actors build upon local and trans-local knowledge, institutional capacity and community coproduction practices to effect change (Boyle \& Harris, 2009; Needham \& Carr, 2009). Reflecting on institutions and public services, we encourage the study of emergent organizing initiatives within which various forms of co-production occur - for example, peer-to-peer. We argue that these can potentially expand our knowledge of how individuals and groups organize under abrupt and rapid transformation, particularly within contexts that face public sector spending cuts, austerity financial policies and severe privatization.

Fourth, romanticizing certain types of collective entrepreneurialism and their capacity to improve the living conditions of vulnerable groups may have contrary effects for already deprived and marginalized communities. Entrepreneurship embodies both emancipation and oppression as contested forces and this may produce paradoxical tensions. Neoliberal economics also mobilize communities and civil society in collaboration and self-employment as a key mechanism for renewing capitalist 
economic activity. Our obligation is to counteract this discourse of 'everyone can become an entrepreneur' and disrupt strategies that may lead to the appropriation of subversive entrepreneurial practice. This disruption does not embrace a protectionist, reactionary and oppositional agenda but inclusivity and self-reflexivity.

Fifth, resisting capitalist appropriation may result in the 'subculturalization' of the subversive (Daskalaki \& Mould, 2013) and condemn initiatives to remain isolated events, a closed system with limited capacity to grow and flourish and hence diminish its transformative potential. Simply adopting an oppositional, inward-looking orientation leaves initiatives' potentialities for experimentation and transformation unrealized. Instead, by embedding and embodying their rhizomatic potentialities, communities can remain in flux and capable of inspiring creative forms of engagement and collaboration (Daskalaki, 2014). These can challenge pre-existing identities and power relations, co-constructing new creative assemblages.

Sixth, challenging fixed entrepreneurial identities, we view these positions as rhizomatic, part of a process during which they can be differentially performed. This performance, transcending boundaries, entails what Deleuze and Guattari (1988) called 'revolutionary connections' and co-constructs new territories of creative collaborative engagements and transformation. Alternative organizational arrangements co-produce 'transformative story-spaces' (Daskalaki, Saliba, Vogiatzis, \& Malamou, 2014) demonstrating the importance of collectivist, participatory and activist intervention by marginalized and disenfranchised populations. Accordingly, critical approaches should reflect and elaborate on the political processes and the tactics through which these populations become embedded into wider societal 
practices, and disrupt and re-organize dominant yet ineffective institutional arrangements.

Finally, art plays a role in foregrounding immanent potentialities of radically subversive initiatives and is stressed in our attempts to unveil these political processes and tactics involved. Aesthetics, as Rancière suggested, is a system determining what presents itself to sense experience, and politics is intimately linked as it '...revolves around what is seen and what can be said about it, around who has the ability to see and the talent to speak, around the properties of spaces and the possibilities of time' (2006, p. 8). Art, a central force in recent social transformation, is a way of presenting ideas and ask questions; art can politically transform and re-order the social. Hence, linking art and entrepreneurial processes work can unveil empirical initiatives and study them as part of wider re-organisation / social transformation processes that coconstitute a new urban, social and economic condition. Crucially artistic (urban) interventions can make visible the immanent potentialities of entrepreneurial events through the enhancement of heterogeneity and dis-ordering, both strategies that characterize activist-artistic communities. Art, in this respect, urges us to locate moments and situations 'yet to come' (Deleuze, 1998) in which the relationships remain subversive, open and, perhaps, constantly re-organized.

\section{Concluding remarks}

Despite sceptical approaches that view alternative organizational formations as nothing more than the latest trend in post-crisis capitalism, individual citizens and collectives appear increasingly committed to changing the way we work, organize private and public life and relate to ourselves and others. Without overestimating the 
activities of these new assemblages, we turned our attention to whether and how they can disrupt traditional institutions (some of them may have been traditionally associated with political action), establish public entrepreneurship as a political act and through that, co-construct new socialities with transformative capacity. Building upon the contributions in this issue, future studies are invited to expand (include different populations, theoretical viewpoints and levels of analysis) and enhance our understanding of how entrepreneurship, communities and social transformation are becoming increasingly related.

\section{References}

Barth, F. (1963). The Role of the Entrepreneur in Social Change in Northern Norway. (Ed.) Bergen: Universitetsforlaget.

Bjerke, B. \& Karlsson, M. (2013). Social Entrepreneurship - to act as if and make a difference, Cheltenham: Edward Elgar.

Boyle, D. \& Harris, M.T. (2009). The Challenge of Co-production. London: NESTA.

Daskalaki, M. (2014). Mobility in Urban Social Events: Towards Organizational Transvergence, Culture and Organization, 20 (3), 215-231.

Daskalaki, M., Saliba, A., Vogiatzis, S. \& Malamou, T. (2014) Story-Spaces and Transformation: The Caravan Project, in Izak, M. L. Hitchin, and D. Anderson (Eds.) Untold Stories in Organizations. (pp. 129-142). London: Routledge.

Daskalaki, M. \& Mould, O. (2013) Beyond Urban Subcultures: Urban Subversions as Rhizomatic Social Formations. International Journal of Urban and Regional Research, 37(1), 1-18.

Deleuze, G. (1998). Essays critical and clinical. Translated by Daniel W. Smith and Michael A. Greco. London: Verso.

Deleuze, G. \& Guattari, F. (1988), A Thousand Plateaus - Capitalism and Schizophrenia. London, UK: The Athlone Press.

de Certeau, M. (1984). The Practice of Everyday Life. Berkeley, CA.: University of California Press.

Fayol, H. \& Matlay, H. (2010). Handbook of Research on Social Entrepreneurship 
(Eds.) Cheltenham: Edward Elgar.

Gartner, W. B., Bird, B. J. \& Starr J. A. (1992). Acting as if: differentiating entrepreneurial from organizational behaviour, Entrepreneurship, Theory \& Practice, 16 (3), 13-31.

Gehman, J., Trevino L. \& Garud, R. (2013). Values Work: A Process Study of the Emergence and Performance of Organizational Values Practices, Academy of Management Journal, 56 (1), 84-112.

Hardt, M. \& Negri, A. (2012). Declaration. Argo Navis.

Hjorth, D. (2003). Rewriting Entrepreneurship - For a New Perspective on Organisational Creativity. Malmö/Copenhagen/Oslo: Liber/CBS Press/Abstrakt.

Hjorth, D. (2012). Organisational Entrepreneurship - An Art of the Weak?, in Hjorth, D. (Ed.) Handbook of Organizational Entrepreneurship. (pp. 169-192). Cheltenham: Edward Elgar.

Hjorth, D. (2013). Public entrepreneurship: desiring social change, creating sociality, Entrepreneurship \& Regional Development: An International Journal, 25 (12), 34-51.

Hjorth, D. \& Bjerke, B. (2006). Public Entrepreneurship - from social/consumer to public/citizen, in Steyaert, C. and Hjorth, D. (Eds.) Entrepreneurship as Social Change (pp. 97-120). Cheltenhamn: Edward Elgar.

Hjorth, D. \& Steyaert, C. (2004). Narrative and Discursive Approaches in Entrepreneurship. (Eds.) Cheltenham: Edward Elgar.

Hjorth, D. \& Steyaert, C. (2009). The Politics and Aesthetics of Entrepreneurship. Cheltenham: Edward Elgar.

Katz, J. (2003). The Chronology and Intellectual Trajectory of American Entrepreneurship Education, Journal of Business Venturing, 18: 283-300.

Katz, J. A. \& W. B. Gartner (1988). Properties of emerging organizations, Academy of Management Review, 13 (3), 429-442.

Kerlin, J. (2010). A Comparative Analysis of the Global Emergence of Social Enterprise. Voluntas: International Journal of Voluntary \& Nonprofit Organizations, 21(2), 162-179.

Kickul, J. \& Bacq, S. (2012) Patterns in Social Entrepreneurship Research (Eds.). Cheltenham: Edward Elgar.

Landström, H. \& Lohrke, F. (2012) Intellectual Roots of Entrepreneurship Research. (Eds.) Cheltenham: Edward Elgar. 
Mair, J. \& Martí, I. (2006). Social entrepreneurship research: A source of explanation, prediction, and delight. Journal of World Business, 41(1), 36-44.

Mair, J., Martí, I. \& Ganly, K. (2007). Social entrepreneurship: Seeing institutional voids as spaces of opportunity. European Business Forum, 31: 34-39.

Mair J., Martí I., \& Ventresca M. (2012). Building Inclusive Markets in Rural Bangladesh: How Intermediaries Work Institutional Voids. Academy of Management Journal, 55(4), 819-850.

Mair, J., Battilana, J., \& Cardenas, J. (2012). Organizing for Society: A Typology of Social Entrepreneuring Models. Journal of Business Ethics, 11(3), 353-373.

Needham, C. \& Carr, S. (2009). Co-production: An Emerging Evidence Base for Adult Social Care Transformation. London: Social Care Institute for Excellence.

Peredo, A. M. \& Chrisman, J. J. (2006). Toward a Theory of Community-Based Enterprise. The Academy of Management Review, 31(2), 309-328.

Rancière, J. (2006). The Politics of Aesthetics, London: Continuum.

Reynolds, P. D. (1991). Sociology and entrepreneurship: Concepts and contributions. Entrepreneurship Theory and Practice, 16(2), 47-70.

Spinosa, C., Flores, F. \& Dreyfus, H. L. (1997). Disclosing new worlds: entrepreneurship, democratic action, and the cultivation of solidarity. Cambridge, Mass: MIT Press.

Stewart, A. (1989) Team Entrepreneurship, Newbury Park CA: SAGE.

Steyaert, C. \& Katz, J. (2004). Reclaiming the space of entrepreneurship in society: geographical, discursive, and social dimensions. Entrepreneurship and Regional Development 16 (3), 179-196.

Steyaert, C. \& Hjorth, D. (2003). New Movements in Entrepreneurship, Cheltenham: Edward Elgar.

Steyaert, C. \& Hjorth, D. (2006). Entrepreneurship as Social Change, Cheltenham: Edward Elgar.

Tedmanson, D., Verduyn, K., Essers, C. \& Gartner, W.B. (2012). Critical P erspectives in Entrepreneurship Research. Organization, 19 (5), 531-541.

Ziegler, R. (2009). An Introduction to Social Entrepreneurship. (Ed.) Cheltenham: Edward Elgar. 